\title{
In silico investigation on the binding of organoselenium compounds with target proteins of SARS-CoV-2 infection cycle
}

\author{
B. G. Singh ${ }^{1,2 *}$, A. Kunwar ${ }^{1,2^{*}}$ \\ ${ }^{1}$ Radiation \& Photochemistry Division, Bhabha Atomic Research Centre, Mumbai-400085, \\ India \\ ${ }^{2}$ Homi Bhabha National Institute, Anushaktinagar, Mumbai -400094, India \\ *Email: beenam@barc.gov.in; kamit@barc.gov.in
}

\begin{abstract}
Since the outbreak of coronavirus disease 2019 (COVID-19), researchers have been investigating the potential of several low molecular weight compounds from both natural and synthetic origins to design anti-viral drugs against SARS-CoV-2. On similar lines, the present study is aimed to evaluate different organoselenium compounds and their sulfur analogues by using a molecular docking approach to inhibit viral proteins like spike (S) glycoprotein (PDB code: 6VXX) and main protease $\left(\mathrm{M}^{\text {pro }}\right.$ ) (PDB code: 6LU7) and a host protein, Furin (PDB code: 5MIM), all of which are known to play significant role in SARS-CoV-2 infection cycle. The organoselenium compounds used in the study are mostly in-house synthesized including simple selenium containing amino acids and their derivatives and selenopyridines and their derivatives. The docking calculations were performed using AutoDock Vina. In brief, organoselenium compounds showed stronger binding with the target proteins as compared to their sulfur analogue, except oxidized glutathione. Notably, the most potent docked ligands shared a common structural feature of aromatic amide moieties connected by diselenide bridge. Further, the compounds ebselen diselenide (EbSeSeEb) and nicotinamide diselenide (NictSeSeNict) exhibited the highest binding affinity (in range of $\sim 10^{5} \mu \mathrm{M}^{-1}$ ) to all the above three proteins. Thus, the present investigation highlights the influence of structure and substitution of organoselenium compound on their binding with the SARS-CoV-2 proteins and proposes NictSeSeNict as a candidate molecule for evaluating anti-viral activity against SARS-CoV-2 using preclinical biological models.
\end{abstract}

Key words: Organoselenium, molecular docking, SARS-CoV-2, binding affinity, therapeutic inhibitor 


\section{Introduction}

Corona viruses $(\mathrm{CoV})$ are a family of viruses containing positive strand ribonucleic acid (RNA) as a genetic material [1]. In past, these viruses have been reported for causing outbreaks like Severe Acute Respiratory Syndrome (SARS) and Middle East Respiratory Syndrome (MERS) in the year 2003 and 2012, respectively [1]. Recently, in December 2019, a similar outbreak of fetal pneumonia was reported from Wuhan, China. The molecular analysis of the bronchiolar lavage fluid (BAL) of these patients indicated the presence of a virus with RNA genome having more than $80 \%$ similarity with SARS-CoV [2]. Accordingly, this virus was named as SARS-CoV-2 by International Virus Classification Commission on February 11, 2020. In a very short period of time, the infection of this virus has spread to several countries and as of today there are nearly 10 million confirmed infections of SARS-CoV-2 worldwide and around 5,03,862 deaths. In view of the increasing infections, World health Organization (WHO) named the SARS-CoV2 induced pathology as COVID-19 and declared this outbreak a pandemic on March 12, 2020. Currently there is no specific treatment available for COVID-19 and therefore the outbreak poses huge threat to humans [2].

With regard to developing of a therapeutic drug against COVID-19, the best strategy is to identify an already approved drug with some other indication for the efficacy against COVID-19. The advantages of using known drugs are that their dosages, route of administration, metabolic characteristics, potential efficacy and side effects are well characterized [3,4]. This process is called drug repurposing and is the fastest way to translate the laboratory results in to clinics. Indeed, there are several clinical trials undergoing at present globally to evaluate several of food and drug administration (FDA) approved drugs for the efficacy against COVID-19. Some of the examples are antiviral drug like Remsdesivir, IL-6 antagonist and hydrocholoroquine (HOCQ) among others. Although these treatment strategies have shown considerable success in the clinical setting, none of these have been approved by FDA as a standard treatment protocol for COVID-19. This warrants the need for the development of vaccine and/or new specific drugs against COVID-19 [2,5].

With the evolving understanding of the pathophysiology of COVID-19, it has emerged that drugs targeting viral processing (entry and its replication within host cells) as well as the associated inflammatory responses could be the potential candidate drug molecules against COVID-19 [6]. 
Extensive research over the years has established that selenium a micronutrient for human plays a very important role in maintaining the immune functions of body and in turn develops resistance against viral infections [7]. Further, it is also known from the literature that selenium deficiency enhances the probability of viral infection as well severity of viral diseases [8-11]. Selenium boosts the immunity of host cells against viral infections by inducing the levels of selenoproteins with antioxidant activities like glutathione peroxidase (GPx) and thioredoxin reductase (TrxR) and altering the cellular redox state with the help of these proteins [7]. In recent times, several of synthetic organoselenium compounds have been reported for various pharmacological activities including anti-inflammatory and anti-viral activities [7]. Indeed, a recent publication in "Nature journal" supports this hypothesis and has revealed that organoselenium compound like Ebselen could be potent inhibitor of viral proteins involved in replication of SARS-CoV2 within host cells [10]. Our group has been working on the similar research area with an objective to develop organoselenium compound as new chemical entity for lung pathology. In this context, we have identified a compound called 3-3'diselenodipropionic acid (DSePA) for its efficacy in preventing the radiation induced pneumonia or inflammatory response in the lung [12]. Additionally, DSePA has advantage of being orally administrable and exhibits maximum absorption in the lung tissues. Its toxicity profile in terms of lethal dose $\left(\mathrm{LD}_{50}\right)$ is also well characterized in rodent models [13]. With this background, it would be worth investigating DSePA and other related oraganodiselenides for possible interaction with viral and host proteins involved in the infection cycle of SARS-CoV-2 to act as inhibitors. In order to address this hypothesis, we used recently reported X-ray structures of spike (S) protein and 3 chymotrypsin-like protease $\left(3 \mathrm{CL}^{\text {pro }}\right)$ or main protease $\left(\mathrm{M}^{\text {pro }}\right)$ from SARS-CoV-2 and Furin protein of human cells for docking with the organoselenium compounds [10, 14,15]. The results were compared with standard drugs like Remsdesivir, HOCQ and Ebselen and N-(tert-Butyl)-2( $N$-arylamido)-2-(pyridin-3-yl) acetamides (ML188), a compound reported in literature for inhibition of $\mathrm{M}^{\text {pro }}$ from SARS-CoV-2 [2, 16-18].

\section{Experimental method}

The structures of the different ligands (shown in scheme 1) for docking were prepared and the structural geometry were minimized on Corina and saved as mol 2 file. All the protein structures were retrieved from protein data bank (www.rcsb.org). The molecular docking was performed on 
AutoDock Vina [19]. Before docking, all the ligands and water molecules in the protein structures were manually removed from the pdb files. The polar hydrogens and Kollman charges were added (at $\mathrm{pH}$ 7) and the protein structure were saved in pdbqt format. Binding site for docking was defined by choosing amino acid residues present in the given domains expressed as grid region-according to the values reported in the literature [20]. The grid values of the different proteins are given below: SARS-CoV-2 S protein:(center_x $=190.45$, center_y $=197.88$, center_z $=260.72$, size_ $\mathrm{x}=61.32$, size $\_\mathrm{y}=41.03$, size $\left.\_\mathrm{z}=43.79\right)$, SARS-CoV-2 main $\mathrm{M}^{\text {pro }}$ protein: $($ center_x $=16.69$, center_y $=27.23$, center_z $=68.46$, size_x $=36.65$, size_y $=42.12$, size_z $=50.40$ ) and human Furin protein: (center_x $=32.41$, center_y $=-37.97$, center_z $=$ 11.64 , size_ $\mathrm{x}=71.93$, size $\_\mathrm{y}=55.05$, size $\left.\_\mathrm{z}=47.46\right)$. The docked ligands were analyzed for non-covalent interactions including hydrogen bonds, electrostatic, Vander Walls and hydrophobic. The scoring function (top docked pose) and the binding energy of the ligands were ranked according to the root mean squire deviation (RMSD) value generated by the building program in Autodock. The octanol-water partition coefficient $(\log \mathrm{P})$ and the binding constant $(\mathrm{K}$ expressed in $\mathrm{M}^{-1}$ ) were estimated using molinspiration software programme [21]. Binding constant was calculated from the energy change value obtained in the form of vina docking scoring function [22]. 
<smiles>NC(C[Se][Se]CC(N)C(=O)O)C(=O)O</smiles>

(1)

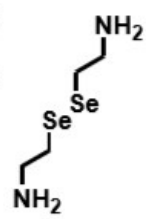

(3)

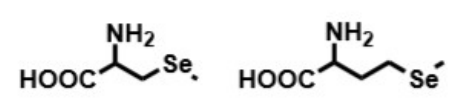

(4)

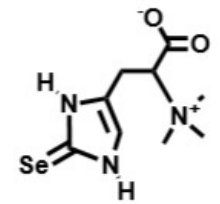

(6)<smiles>[R5]C[C@H](NC(=O)CC[C@H](N)C(=O)O)C(=O)NCC(=O)O</smiles>

(7)

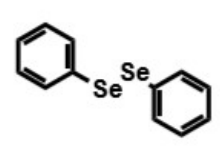

(8)<smiles>OC1C[Se]CC1O</smiles>

(9)<smiles>C[Se](=O)O</smiles>

(10)<smiles>NC(N)=[Se]</smiles>

(11)

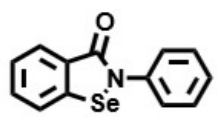

(12)<smiles>O=C(Nc1ccccc1)c1ccccc1S(=O)(=O)[O-]</smiles>

(13)

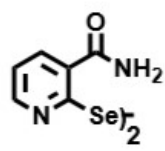

(14)<smiles>Oc1cccnc1S</smiles>

(15)<smiles>O=C(O)c1cccnc1S(=O)(=O)O</smiles>

(16)<smiles>[AsH3][As]c1ccncc1</smiles>

(17)

(18)<smiles>O=C(Nc1ccccc1)c1ccccc1S</smiles>

(19)<smiles>NC(=O)c1ccc[nH]c1=[Se]</smiles>

(20)<smiles>NC(=O)c1cccnc1</smiles>

(21)

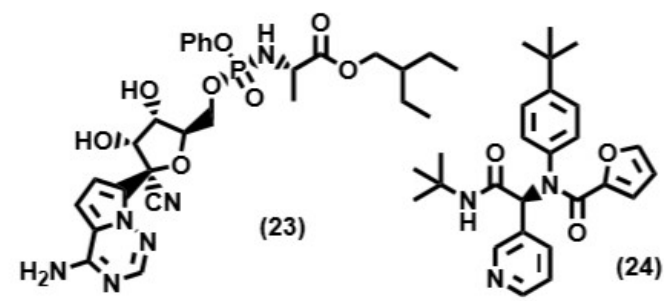

Scheme 1: Structure of the organoselenium compounds screened for docking; 1. Diselenodipropanoic acid (DSePA), 2. Selenocystine (CysSeSeCys), 3. Selenocystamine (DSePAmine), 4. Methyl selenocysteine (MeSeCys), 5. Selenomethionine (SeM), 6. Selenoneine (SeHis), 7. Selenoglutathioneoxi (GSeSeG), 8. Diphenyl diselenide (PhSeSePh), 9. Dihydroxyl selenolane (DHS), 10. Methaneseleninic acid (MSeA), 11. Selenourea (SeU), 12. Ebselen (EbSe), 13. Ebselen diselenide (EbSeSeEb), 14. Nicotinamide diselenide (NictSeSeNict), 15. Pyridinol diselenide (HOPySeSePyOH), 16. Nicotinic acid diselenide (CarPySeSePyCar), 17. 2pyridine diselenide (2-PySeSePy), 18. 4-pyridine diselenide (4-PySeSePy), 19. Ebselenol $(\mathrm{EbSeH}), 20$. Nicotinamide selone (NictSe), 21. Nicotinamide, 22. Hydroxylchloroquine (HOCQ), 23. Remdesvir and 24. ML188. The analogous organosulfur compounds having selenium replaced by sulfur were also screened for docking.

\section{Results}

The genome of SARS-CoV-2 carries the information for structural proteins like S protein, envelope $(\mathrm{E})$ protein, membrane $(\mathrm{M})$ protein, nucleocapsid $(\mathrm{N})$ protein and non-structural protein like replicase polyprotein $[10,14,15]$. The structural proteins are involved in the formation of 
viral coat and the packaging of the RNA genome. The polyproteins undergo proteolytic cleavage to release function proteins involved in viral replication and transcription by viral protease, $3 \mathrm{CL}^{\text {pro }}$ or $\mathrm{M}^{\text {pro }}$ which by itself is released from polyproteins through autolytic cleavage [10, 14,15]. The $\mathrm{S}$ protein present in viral coat interacts with host cell receptor like angiotensinconverting enzyme 2 (ACE2) to facilitate its entry into host cells (like lung epithelium). The functional importance of $\mathrm{S}$ and $\mathrm{M}^{\text {pro }}$ in establishing SARS-CoV2 infection as well as the absence of a closely related homologue of these proteins in humans, proposes them as an attractive target for the design of anti-viral drugs $[23,26]$. Additionally, few reports have suggested that Furin a trans-membrane protease present on the plasma membrane of host cell may also be playing a very crucial role in the entry of SARS-CoV-2 virus within cells [27]. As per these reports, Furin may be involved in the proteolytic processing of S protein to make its conformation suitable for binding on ACE2 receptors. Accordingly, Furin also qualifies as a target protein for screening of anti-viral compounds. The binding energy and the corresponding affinity constant of all the tested compounds (Scheme 1) with S, $\mathrm{M}^{\text {pro }}$ and Furin proteins are listed in Table 1 and Table 2 respectively. It can be seen that organoselenium compounds of varying functional groups exhibited strong interactions with all the three proteins with binding energy ranging from -3.0 $\mathrm{kcal} / \mathrm{mol}$ to $-9.0 \mathrm{kcal} / \mathrm{mol}$ and binding constant from $1.9 \mathrm{mM}^{-1}$ to $0.2 \mu \mathrm{M}^{-1}$. Among the tested compounds, selenium derivatives showed better interaction with the target proteins than the corresponding sulfur derivatives except GSSG whose binding affinity was higher than GSeSeG. The analysis of the nature of interactions revealed that the organoselenium and their sulfur analogs interacted with target proteins through hydrogen bonding and/or Vander Waals interaction and/or alkyl interactions depending on the functional groups attached to their backbone structure (Table 3-5). The higher affinity of selenium compounds as compared to their sulfur derivatives is attributed to the higher contribution of Vander Waal interaction which arises due to the higher polarizability of selenium atom [28]. Further, it was also observed that irrespective of the presence of selenium or sulfur, the aliphatic compounds showed lower binding affinity as compared to the aromatic derivatives. This is attributed to the induction of pi-alkyl and hydrophobic interactions along with the conventional hydrogen and Vander Waal bonding commonly observed with aliphatic compounds (Table 2). The most potent compounds showing the lowest binding energy or the highest affinity for $\mathrm{S}, \mathrm{M}^{\mathrm{pro}}$ and Furin proteins identified from the present docking analysis were EbSeSeEb and NictSeSeNict (Table 1 and Table 2). Among the 
standards, Remsdesivir showed highest affinity for $\mathrm{S}$ and Furin proteins. Ebselen showed maximum affinity for $\mathrm{M}^{\text {pro }}$ and HOCQ showed moderate affinity to all the three proteins. The binding affinity of EbSeSeEb and NictSeSeNict for $\mathrm{S}$ and Furin proteins was comparable to Remsdesivir and better than HOCQ, Ebselen and ML188. Similarly the binding affinity of these compounds for $\mathrm{M}^{\text {pro }}$ was better than all the four standards. The best binding pose of the representative molecules with the individual target protein is presented in figures 1-3. The nature of the interactions of representative aliphatic (selenoamino acid) and aromatic (selenopyridines) organoselenium compounds and their sulfur analogues with the individual target protein are discussed in detail under following sections.

\section{Interaction with $\mathbf{S}$ protein}

The S protein, a homotrimeric glycoprotein interacts with host receptor, ACE2 via the receptorbinding domain (RBD). The RBD is known to exist in at least two primary conformational states called the up (receptor-accessible) and down (receptor-inaccessible) states. When the RBD is in the up state, the S protein is more "open" to facilitate the binding of ACE2. Studies have suggested that the down, receptor-inaccessible state, is more stable [29]. This implies that low molecular weight molecules capable of stabilizing the RBD in the down state could prevent the virus from interacting with ACE2 and thus, limiting the spread of SARS-CoV-2 [30]. Thus, for the present study, the down conformation of the $\mathrm{S}$ protein from SARS-CoV-2 (PDB code: $6 \mathrm{VXX}$ ) was used for docking (Table 1, 2 \& 3). The RBD region in $\mathrm{S}$ protein lies from residues 331 to 524, while the most important amino acid residues responsible for binding of $\mathrm{S}$ protein with ACE2 are from 415 to 505 [31-33]. Notably, DSePA an aliphatic diselenide interacted with the RBD motif of $\mathrm{S}$ protein through conventional hydrogen bonding involved between its carboxylate group and Arg408, Gln409 and Lys417 residues. Additionally, aliphatic and diselenide moieties of DSePA are involved in Vander Waals interaction with the amino acid residue as shown in Table 3. Another structurally related aliphatic diselenide, CysSeSeCys, where an additional amino group is present as compared to DSePA, the diselenide moiety showed alkyl interaction with Lys375 and Cys379 residues in addition to the hydrogen bonding of carboxylate group with Tyr369, Ser383, Thr415, Gln414, Arg408, Pro384 and Ser383 residues (Table 3). Further amino group of CysSeSeCys was found to be involved in hydrogen bonding with Thr415, an amino acid present in the RBD of S protein. This results an increase in the binding affinity of CysSeSeCys towards $\mathrm{S}$ protein as compared to DSePA (Interaction as 
depicted in Table 3). On increasing the number of peptide bond as seen in GSeSeG and GSSG, the number of conventional bonds increased which was reflected in the increase in the binding energy of these compounds with the S-protein. Also, the number of interactions observed is more in case of GSSG as compared to GSeSeG, which may be attributed to the size of the molecule to fit in the binding site. This results in the higher binding affinity of GSSG as compared GSeSeG towards S protein. Further, comparing the binding energy of aromatic organoselenium compounds with different functional group such as carboxylate (CarPySeSePyCar), hydroxy (HOPySeSePyOH) and amide (NictSeSeNict), indicated that the compounds with amide functional group showed higher binding with $\mathrm{S}$ protein (Table $1 \& 2$ ). This increase in binding energy may be attributed to the hydrogen bonding between - NH atoms of amide with Thr415 of the protein (Table -3). Similarly, the influence of heterocyclic diselenide can be compared from the values obtained for EbSeSeEb and NictSeSeNict. The presence of the N-heterocyclic ring is found to influence the binding of the compound slightly away from the Thr415 residue. Whereas simple aromatic ring as seen in Ebselen and its diselenide binds to Thr415, thus explaining their increased affinity for S-protein (Table -3). Further, the binding affinity of selone (the monoselenide) form of NictSeSeNict was lesser as compared to the diselenide form (Table $1 \&$ 2). Similarly, plain ligand, nicotinamide without selenium moiety was also docked to evaluate the influence of selenium atom in the binding. It was observed that the binding affinity of the nictotiamide ligand was similar to that of the selone form (Table $1 \& 2$ ). Together these results pointed out the role of diselenide bridge in increasing the affinity of aromatic organoselenium compounds towards $\mathrm{S}$ protein (Scheme 1, Table $1 \& 2$ ). It can also be argued that two nicotinamide moieties connected by carbon bonds may also show good affinity for S-protein. However, synthesis of such compounds may not be easy and are also expected to be unstable. On contrary, the diselenide bond may act as a linker to form the dinicotinamide moiety to get the desired activity.

\section{Interaction with $M^{\text {pro }}$ protein}

$\mathrm{M}^{\mathrm{pro}}$ protein is a homodimer comprising of three domains. The domain I (residue 8-101), domain II (residue 102-184) and domain III (residue 201-203) and a long loop (residues 201-303) [34]. The catalytic region is formed by the dyad His41-Cys145 that is highly conserved among the $\mathrm{CoV}$ proteases. This probable binding site for substrates is located in a cleft region between domains I and II, which is similar to that observed in the trypsin-like serine proteases. Table 4 
shows the nature of the binding interactions of representative compounds with $\mathrm{M}^{\text {pro }} \mathrm{SARS}-\mathrm{CoV}$ 2. The binding energy of DSePA to this viral protein was found to be lower than the other organoselenium compounds but was still higher than the standard drugs like Remdesvir and HOCQ (Table $1 \& 2$ ). The carboxylate group of DSePA was involved in the hydrogen bonding with Gly23, Cys22, Asn45, Thr24, Thr25, whereas the aliphatic alkyl diselenide chain was involved in Vander Waal interaction. The binding site of DSePA was located in domain I and is slightly away from the active site. Similarly, in case of CySeSeCys, the amino acid residues Asp48, Ile43, Lys61, Cys44, Cys22 and Thr25 are involved in hydrogen bonding with the amino and carboxylate groups of the diselenide. Like DSePA, CysSeSeCys also binds with the amino acids in extreme right side of domain I, and these factors may be responsible for the low binding of DSePA and CysSeSeCys with $\mathrm{M}^{\text {pro }}$ as compared to other organoselenium compounds. Further, a long chain aliphatic diselenide like GSeSeG showed higher affinity towards the catalytic domain of $\mathrm{M}^{\text {pro }}$ due to increase in the number of hydrogen bonding interactions (Table 1, 2\& 4). Interestingly, its sulfur analog, GSSG, exhibited further increase in its affinity for $\mathrm{M}^{\text {pro }}$ and this is attributed to pi-alkyl interaction with Cys845 residue present at the interface between the domain I and II along with the conventional hydrogen bonding. Among aromatic compounds, Ebselen showed binding with the amino acid residues present in the domain I but slightly towards the end of domain I. On the other hand, aromatic diselenides, NictSeSeNict and EbSeSeEb, interacted with $\mathrm{M}^{\text {pro }}$ at the interface and near the catalytic site. The amide functional group in these molecules were involved in hydrogen bonding with polar amino residues, but the presence of aromatic ring increased their interaction with $\mathrm{M}^{\text {pro }}$ by induction of hydrophobic and pi-alkyl interactions. The corresponding monoselenides of NictSeSeNict and EbSeSeEb showed lesser binding affinity for $\mathrm{M}^{\text {pro }}$ (Table $\left.1 \& 2\right)$.

\section{Interaction with Furin protein}

Furin protease has binding site from residue 109 to 574, with presence of catalytic traid Asp153His 194-Ser368 and an additional oxyanion hole at Asn295 [35]. Along with the active site, this protein has also allosteric sites, where inhibitors can bind and change the conformation of the active site. Unlike viral proteins discussed in above sections, the binding affinity of DSePA and CysSeSeCys for Furin was comparable mainly due to the unfavorable interaction of CysSeSeCys carboxylate group with Gln488 (Table 1, 2 \& 5). GSSG and GSeSeG showed binding to the 
catalytic traid residues, Ser368 (hydrogen bonding), Asp153 and His194 (Vander Waals interaction) along with Asn295. This indicated that these compounds may be potent Furin protease inhibitors (Table 1, 2 \& 5). Further among the aromatic diselenides, EbSeSeEb showed binding to allosteric site (Lu331, Asp301 and His300) via Vander Waal interactions (Table 5). Also, NictSeSeNict showed allosteric binding to amino acid residues Tyr369 (hydrogen bonding), Arg408 (pi-cation, electrostatic attraction) and Arg409 (Vander Waal interaction) (Table 5). The binding affinities of the plain ligands and the monoselenide forms of these compounds for Furin protein were lower as compared to respective Diselenides (Table 1 \& 2).

\section{Discussion}

Since the outbreak of COVID-19 in early 2020, a lot of research has already been done and/or initiated for designing anti-viral drugs against SARS-CoV-2 using virtual screening or molecular docking approach [2-4]. Most of these studied have focused on evaluating FDA approved drugs with an intent of repurposing as well as phytochemicals obtained from natural sources for their abilities to inhibit viral and host proteins involved in the infection cycle of SARS-CoV-2. However, there is no such report available on the synthetic organoselenium compounds known for various pharmacological activities. The present study was planned to address this issue.

Notably, $\mathrm{S}$ and $\mathrm{M}^{\text {pro }}$ proteins from SARS-COV-2 share a very high degree of sequence and structural homology with the similar proteins reported from another virus SARS-CoV of the same family $[10,14,15]$. Therefore, these proteins have been extensively investigated over the years to design small molecules to inhibit their activities. This has led to the identification of the most potent inhibitor known as ML188 against $\mathrm{M}^{\text {pro }}$ protein of SARS-CoV [16]. On similar lines, recently Macchiagodena et al applied computation strategy to design several structure-based ligands for $\mathrm{M}^{\text {pro }}$ protein of SARS-CoV-2 and reported that synthetic molecules with aromatic moieties connected by rotable double bonds in a pseudo-linear arrangement could be the potential inhibitors of this protein [33]. In concurrence with this report, our results confirmed that organoselenium compounds showing higher affinity to target proteins such as $\mathrm{S}, \mathrm{M}^{\text {pro }}$ and Furin shared a common structural feature of aromatic amide moieties connected by diselenide bridge. Importantly, present study indicated that organodiselenides like EbSeSeEb and NictSeSeNict may be more active in inhibiting the chosen protein targets (S, $\mathrm{M}^{\text {pro }}$ and Furin) than ML188 and standard drugs like Remdesvir, Ebselen and HOCQ evaluated under similar docking conditions. 
Since both EbSeSeEb and NictSeSeNict have previously been reported for antioxidant activity in acellular and cellular models [36-39], the above observations gain a lot of significance for future designing of anti-viral drugs. Additionally, the superiority of EbSeSeEb over the parent compound, Ebselen is also an important finding in view of the recently demonstrated anti-viral activity of this compound against SARS-CoV-2 [10].

The protein-ligand interaction is mainly governed by two major forces, the covalent and noncovalent interactions. The covalent inhibitors are generally not preferred for drug development programme because of their expected toxicity resulting from non-specific inhibition of intracellular enzymes and proteins involved in the normal cellular functioning [40]. In present study, although the tested compounds were evaluated only for the noncovalent interactions with the target proteins, their involvement in establishing covalent interactions with the target proteins cannot be ignored. This assumption is justified considering the fact that organodiselenides and their reactive metabolic intermediates like selenols are well documented to nonspecifically interact with sulfur containing amino acid (cysteine) of cellular proteins through formation of selenotrisulfide (S-Se-S) or selenenylsulfide (S-Se) or disulfide (S-S) or diselenide (Se-Se) bonds [28]. Moreover, orgnodiselenides are also known to be metabolically unstable and are immediately converted to corresponding selenol or selone by reacting with cellular thiols (mainly GSH) $[28,37]$. Therefore, the availability of organoselenium in the diselenide form at the site of infection like lung tissue could also be a concern in the development of such molecules as antiSARS-CoV-2 drugs. Notably, our docking analysis has indicated that selenol and/or selone form of EbSeSeEb and NictSeSeNict also exhibit the considerable affinity (in range of $\sim 10^{6} \mu \mathrm{M}^{-1}$ ) towards the target proteins. Therefore, both $\mathrm{EbSeSeEb}$ and NictSeSeNict appear to be candidate molecules for future exploration of their anti-viral activities using recombinant proteins and in vivo models.

Nevertheless, these compounds also need to be fully characterized for their side effects or toxicities before being considered for in vivo studies. In this context, aliphatic diselenides such as DSePA and CysSeSeCys (which are also structural analogues) have been extensively studied for their toxicities in cellular models and their safe dosage are already established for animal models $[12,13,41]$. Of these, DSePA is also reported for anti-inflammatory activity in the lung of mice. Therefore, although DSePA and CysSeSeCys exhibited moderate affinities for S, $\mathrm{M}^{\text {pro }}$ and Furin 
proteins, it will be worth evaluating these compounds for suppressing or delaying the pneumonia associated with COVID-19. However, this hypothesis needs to be rigorously tested using preclinical models.

\section{Conclusions}

The present investigation revealed that organoselenium compounds can exhibit higher binding affinity to the SARS-CoV-2 proteins and can be candidate molecules for designing anti-viral drug. Among the library of 18 organoselenium and their analogous organosulfur compounds studied in present work, NictSeSeNict and EbSeSeEb showed the highest affinity for two viral proteins namely $\mathrm{S}$ and $\mathrm{M}^{\text {pro }}$ and a host protein Furin. The present study also reports important structural features dictating the interaction of organoselenium compound with the viral proteins. These results are only preliminary screening and our future studies will be focused to evaluate the most potent ones using recombinant viral proteins and active viruses.

\section{Acknowledgement}

Authors thank Dr. Awadhesh Kumar, HOD, RPCD and Dr. A. K. Tyagi, Associate Director, Chemistry Group for the support and encouragement during the course of study.

\section{Conflict of interest: None}

\section{References}

1. Fehr AR, Perlman S. Coronaviruses: an overview of their replication and pathogenesis. Methods Mol. Biol. 2015, 1282, 1-23.

2. Liu C, Zhou Q, Li Y, Garner LV, Watkins SP, Carter LJ, Smoot J, Gregg AC, Daniels AD, Jervey S, Albaiu D. Research and development on therapeutic agents and vaccines for COVID19 and related human coronavirus diseases. ACS Cent. Sci. 2020, 6, 315-331.

3. Scavone C, Brusco S, Bertini M, Sportiello L, Rafaniello C, Zoccoli A, Berrino L, Racagni G, Rossi F, Capuano A. Current pharmacological treatments for COVID-19: What's next? Br. J. Pharmacol. 2020, doi: 10.1111/bph.15072. 
4. Serafin MB, Bottega A, Foletto VS, da Rosa TF, Hörner A, Hörner R. Drug repositioning is an alternative for the treatment of coronavirus COVID-19. Int. J. Antimicrob. Agents. 2020, 55, $105969-105973$.

5. Amawi H, Abu Deiab GI, A Aljabali AA, Dua K, Tambuwala MM. COVID-19 pandemic: an overview of epidemiology, pathogenesis, diagnostics and potential vaccines and therapeutics. Ther. Deliv. 2020 11, 245-268.

6. Gordon DE, Jang GM, Bouhaddou M, Xu J, Obernier K, White KM, O'Meara MJ, Rezelj VV, Guo JZ, Swaney DL, Tummino TA, Huettenhain R, Kaake RM, Richards AL, Tutuncuoglu B, Foussard H, Batra J, Haas K, Modak M, Kim M, Haas P, Polacco BJ, Braberg H, Fabius JM, Eckhardt M, Soucheray M, Bennett MJ, Cakir M, McGregor MJ, Li Q, Meyer B, Roesch F, Vallet T, Mac Kain A, Miorin L, Moreno E, Naing ZZC, Zhou Y, Peng S, Shi Y, Zhang Z, Shen W, Kirby IT, Melnyk JE, Chorba JS, Lou K, Dai SA, Barrio-Hernandez I, Memon D, Hernandez-Armenta C, Lyu J, Mathy CJP, Perica T, Pilla KB, Ganesan SJ, Saltzberg DJ, Rakesh R, Liu X, Rosenthal SB, Calviello L, Venkataramanan S, Liboy-Lugo J, Lin Y, Huang XP, Liu Y, Wankowicz SA, Bohn M, Safari M, Ugur FS, Koh C, Savar NS, Tran QD, Shengjuler D, Fletcher SJ, O'Neal MC, Cai Y, Chang JCJ, Broadhurst DJ, Klippsten S, Sharp PP, Wenzell NA, Kuzuoglu D, Wang HY, Trenker R, Young JM, Cavero DA, Hiatt J, Roth TL, Rathore U, Subramanian A, Noack J, Hubert M, Stroud RM, Frankel AD, Rosenberg OS, Verba KA, Agard DA, Ott M, Emerman M, Jura N, von Zastrow M, Verdin E, Ashworth A, Schwartz O, d'Enfert C, Mukherjee S, Jacobson M, Malik HS, Fujimori DG, Ideker T, Craik CS, Floor SN, Fraser JS, Gross JD, Sali A, Roth BL, Ruggero D, Taunton J, Kortemme T, Beltrao P, Vignuzzi M, GarcíaSastre A, Shokat KM, Shoichet BK, Krogan NJ. A SARS-CoV-2 protein interaction map reveals targets for drug repurposing. Nature, 2020, doi: 10.1038/s41586-020-2286-9.

7. Guillin OM, Vindry C, Ohlmann T, Chavatte L. Selenium, selenoproteins and viral infection. Nutrients. 2019, 11, 2101-2133.

8. Sancineto L, Mariotti A, Bagnoli L, Marini F, Desantis J, Iraci N, Santi C, Pannecouque C, Tabarrini O. Design and Synthesis of DiselenoBisBenzamides (DISeBAs) as Nucleocapsid Protein 7 (NCp7) Inhibitors with anti-HIV Activity. J. Med. Chem. 2015, 58, 9601-9614. 
9. Sahu PK, Umme T, Yu J, Nayak A, Kim G, Noh M, Lee JY, Kim DD, Jeong LS. Selenoacyclovir and selenoganciclovir: discovery of a new template for antiviral agents. J. Med. Chem. 2015, 58, 8734-8738.

10. Jin Z, Du X, Xu Y, Deng Y, Liu M, Zhao Y, Zhang B, Li X, Zhang L, Peng C, Duan Y, Yu J, Wang L, Yang K, Liu F, Jiang R, Yang X, You T, Liu X, Yang X, Bai F, Liu H, Liu X,

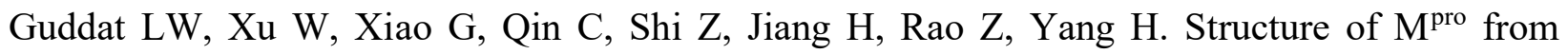
SARS-CoV-2 and discovery of its inhibitors. Nature. 2020, 582, 289-293.

11. Zhang J, Taylor EW, Bennett K, Saad R, Rayman MP, Association between regional selenium status and reported outcome of COVID-19 cases in China. Am. J. Clin. Nutr. 2020, $111,1297-1299$.

12. Gandhi KA, Goda JS, GandhiVV, Sadanpurwala A, Jain VK, Joshi K, Epari S, Rane S, Mohanty, Chaudhary P, Kembhavi S, Kunwar A, Gota V, Priyadarsini KI, Oral administration of 3,3'-diselenodipropionic acid prevents thoracic radiation induced pneumonitis in mice by suppressing NF-kB/IL-17/G-CSF/neutrophil axis. Free Radic. Biol. Med. 2019, 145, 8-19.

13. Kunwar A, Patil A, Kumar S, Deshpande R, Gota V, Goda JS, Jain VK, Priyadarsini KI, Toxicological safety evaluation of 3, 3'-diselenodipropionic acid (DSePA), a pharmacologically important derivative of selenocystine. Regul. Toxicol. Pharmacol. 2018, 99, 159-167.

14. Yan R, Zhang Y, Li Y, Xia L, Guo Y\& Zhou Q, Structural basis for the recognition of SARS-CoV-2 by full-length human ACE2. Science. 2020, 367, 1444-1448.

15. Walls AC, Park Y-J, Tortorici MA, Wall A, McGuire AT, Veesler D, Structure, function, and antigenicity of the SARS-CoV-2 spike glycoprotein. Cell. 2020, 181, 281-292.

16. Jacobs J, Grum-Tokars V, Zhou Y, Turlington M, Saldanha SA, Chase P, Eggler A, Dawson ES, Baez-Santos YM, Tomar S, Mielech AM, Baker SC, Lindsley CW, Hodder P, Mesecar A, Stauffer SR, Discovery, synthesis, and structure-based optimization of a series of N-(tert-Butyl)2-(N-arylamido)-2-(pyridin-3-yl) Acetamides (ML188) as potent noncovalent small molecule inhibitors of the Severe Acute Respiratory Syndrome Coronavirus (SARS-CoV) 3CL protease. $J$. Med. Chem. 2013, 56, 534-546 
17. Padmanaban G , Nagaraj VA, Hydroxychloroquine: a relatively obscure antimalarial takes centre stage in COVID-19. Curr. Sci. 2020, 118, 1489-1491.

18. Das S, Bhowmick S, Tiwari S, Sen S, An updated systematic review of the therapeutic role of Hydroxychloroquine in coronavirus disease-19 (COVID-19). Clin. Drug. Investig. 2020, 40, 591-601.

19. Huey R, Morris GM, Olson AJ, Goodsell DS, A semiempirical free energy force field with charge-based desolvation. J. Comput. Chem. 2007, 28, 1145-1152.

20. D. Maurya, D. Sharma C, Evaluation of traditional ayurvedic preparation for prevention and management of the novel coronavirus (SARS-CoV-2) using molecular docking approach. Chem. Rxiv. 2020, doi: 10.26434/chemrxiv.12110214 .

21. Molinspiration Cheminformatics free web services, https://www.molinspiration.com

22. Sargis Dallakyan http://autodock.1369657.n2.nabble.com/

23. Tai W, He L, Zhang X, Pu J, Voronin D, Jiang S, Zhou Y, Du L. Characterization of the receptor-binding domain (RBD) of 2019 novel coronavirus: implication for development of RBD protein as a viral attachment inhibitor and vaccine. Cell Mol. Immunol. 2020, 17, 613-620.

24. Shang J, Ye G, Shi K, Wan Y, Luo C, Aihara H, Geng Q, Auerbach A, Li F. Structural basis of receptor recognition by SARS-CoV-2. Nature. 2020, 581, 221-224.

25. Yi C, Sun X, Ye J, Ding L, Liu M, Yang Z, Lu X, Zhang Y, Ma L, Gu W, Qu A, Xu J, Shi Z, Ling Z, Sun B. Key residues of the receptor binding motif in the spike protein of SARS-CoV-2 that interact with ACE2 and neutralizing antibodies. Cell Mol. Immunol. 2020, 17, 621-630.

26. Shang J, Wan Y, Luo C, Ye G, Geng Q, Auerbach A, Li F. Cell entry mechanisms of SARSCoV-2. Proc. Natl. Acad. Sci. U S A. 2020, 117, 11727-11734.

27. Tang T, Bidon M, Jaimes JA, Whittaker GR, Daniel S. Coronavirus membrane fusion mechanism offers a potential target for antiviral development. Antiviral Res. 2020, 178, 104792104808 .

28. Wessjohann LA, Schneider A, Abbas M, Brandt W. Selenium in chemistry and biochemistry in comparison to sulfur. Biol. Chem. 2007, 388, 997-1006. 
29. Wrapp D, Wang N, Corbett KS, Goldsmith JA, Hsieh CL, Abiona O, Graham BS, McLellan JS, Cryo-EM structure of the 2019-nCoV spike in the prefusion conformation. Science. 2020, $367,1260-1263$.

30. Zhang L, Lin D, Sun X, Curth U, Drosten C, Sauerhering L, Becker S, Rox K, Hilgenfeld R, Crystal structure of SARS-CoV-2 main protease provides a basis for design of improved $\alpha-$ ketoamide inhibitors. Science. 2020, 368, 409-412.

31 Calligari P, Bobone S, Ricci G, Bocedi A. Molecular investigation of SARS-CoV-2 proteins and their interactions with antiviral drugs. Viruses. 2020, 12, 445-458.

32. Wang L, Wang Y, Ye D, Liu Q, Review of the 2019 novel coronavirus (SARS-CoV-2) based on current evidence. Int. J. Antimicrob. Agents. 2020, 55, 105948- 105955.

33. Macchiagodena M, Pagliai M, Procacci P. Identification of potential binders of the main protease $3 \mathrm{CL}^{\text {pro }}$ of the COVID-19 via structure-based ligand design and molecular modeling. Chem. Phys. Lett. 2020, 750, 137489- 137493.

34. Chang GG. Quaternary structure of the SARS coronavirus main protease. Molecular Biology of the SARS-Coronavirus. S.K. Lal (ed.), Springer-Verlag Berlin Heidelberg, 2009, 115-128.

35. Kibirev VK, Osadchuk TV, Kozachenko OP, Kholodovych V, Fedoryak D, Brovarets VS. Synthesis, biological evaluation and docking of novel bisamidinohydrazones as non-peptide inhibitors of furin. Ukr. Biochem. J. 2015, 87, 55-63.

36. Mishra B, Priyadarsini KI, Mohan H, Mugesh G. Horseradish peroxidase inhibition and antioxidant activity of ebselen and related organoselenium compounds. Bioorg. Med. Chem. Lett. 2006, 16, 5334-5338.

37. Prabhu P, Singh BG, Noguchi M, Phadnis PP, Jain VK, Iwaoka M, Priyadarsini KI. Stable selones in glutathione-peroxidase-like catalytic cycle of selenonicotinamide derivative. Org. Biomol. Chem. 2014, 12, 2404-2412.

38. Raghuraman M, Verma P, Kunwar A, Phadnis PP, Jain VK, Priyadarsini KI, Cellular evaluation of diselenonicotinamide (DSNA) as a radioprotector against cell death and DNA damage. Metallomics, 2017, 9, 715-725. 
39. Zhao R, Holmgren A, A novel antioxidant mechanism of ebselen involving ebselendiselenide, a substrate of mammalian thioredoxin and thioredoxin reductase. J. Biol. Chem. 2002, 277, 39456-39462.

40. Aljoundi A, Bjij I, El Rashedy A, Soliman MES, Covalent Versus Non-covalent Enzyme Inhibition: Which Route Should We Take? A Justification of the Good and Bad from Molecular Modelling Perspective. Protein J. 2020, 39, 97-105.

41. Alvarez-Perez M, Ali W, Marc MA, Dominguez-Alvarez JHE, Selenides and diselenides: a review of their anticancer and chemopreventive activity. Molecules. 2018, 23. 
Fig. 1: Low energy binding conformation of (A) DSePA (B) CysSeSeCys (C) GSSG (D) EbSeSeEb and (E) NictSeSeNict with S protein (PDB code: 6VXX) of SARS-CoV2. Images (a) and (b) show the entire protein and the protein site bound with the ligand, respectively.
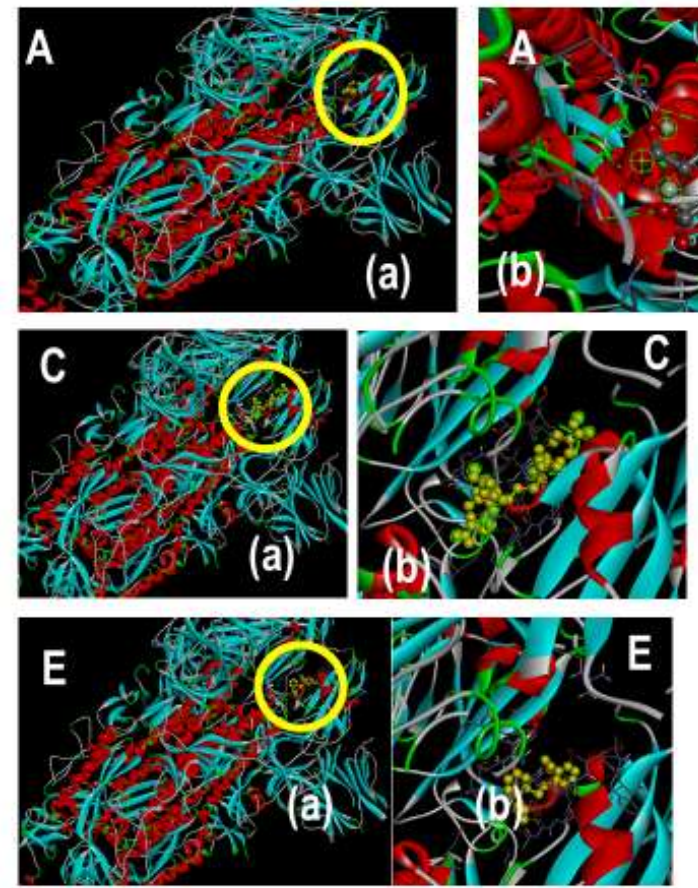
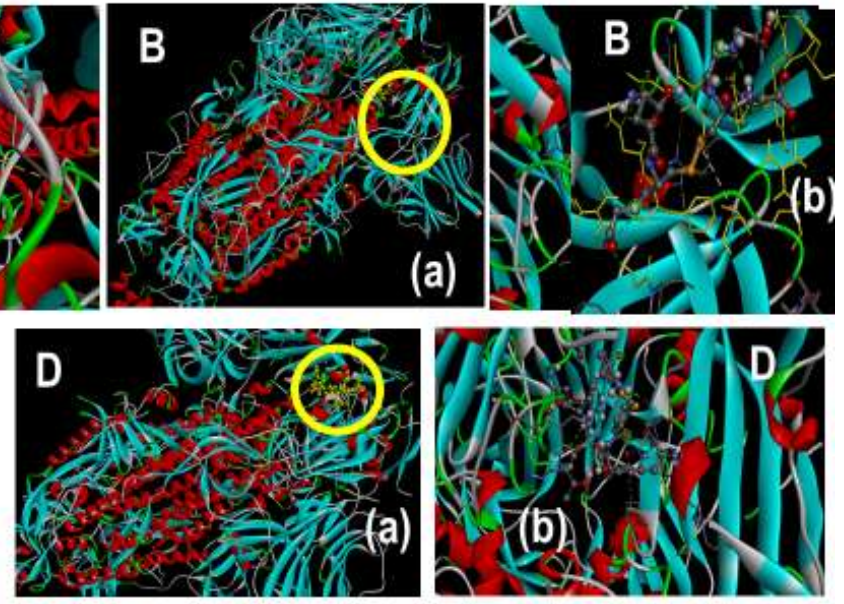
Fig. 2: Low energy binding conformation of (A) DSePA (B) GSSG (C) EbSeSeEb and (D) NictSeSeNict with $M^{\text {pro }}$ protein (PDB: 6LU7) of SARS-CoV2. Image (a) and (b) shows the entire protein and the protein site bound with the ligand, respectively.
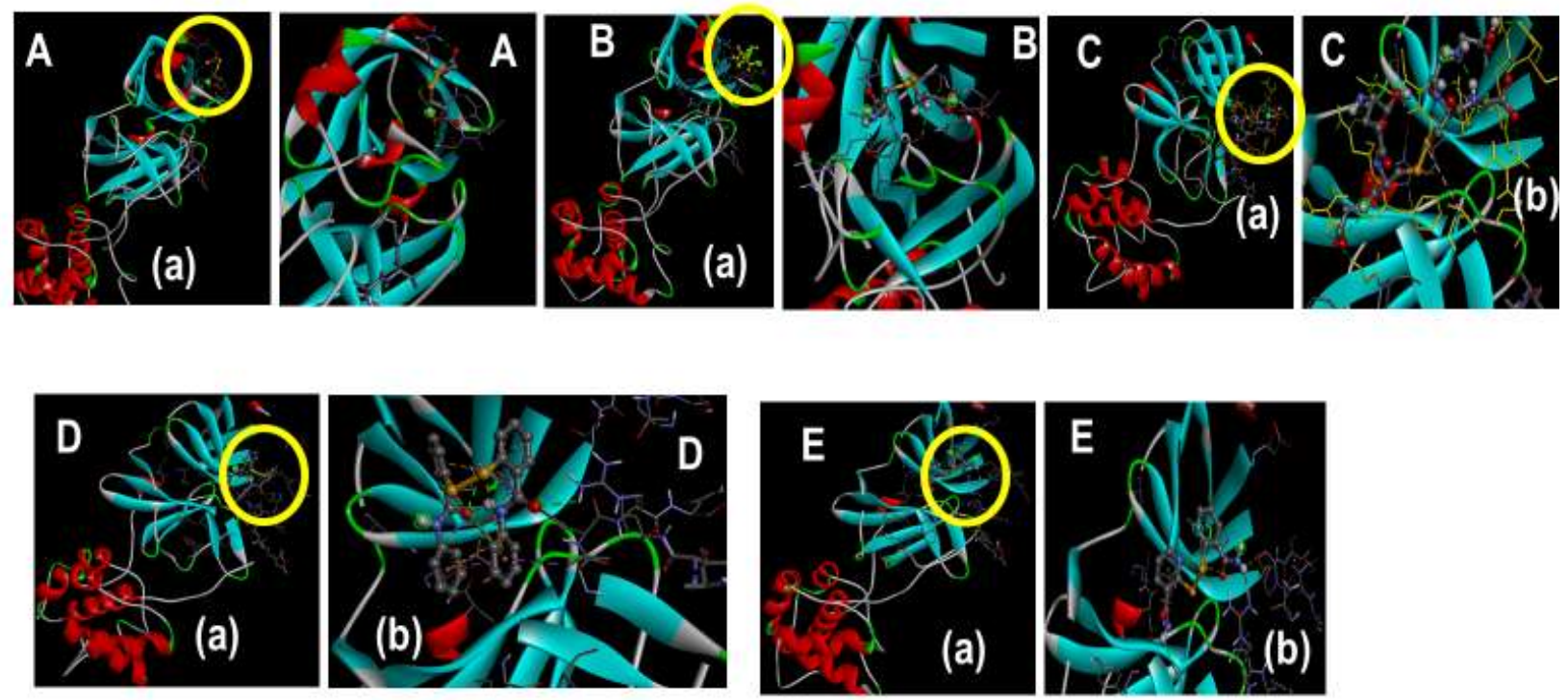
Fig. 3: Low energy binding conformation of (A) DSePA (B) GSSG (C) EbSeSeEb and (D) NictSeSeNictwith human Furin protein. Image (a) and (b) shows the entire protein and the protein site bound with the ligand, respectively.
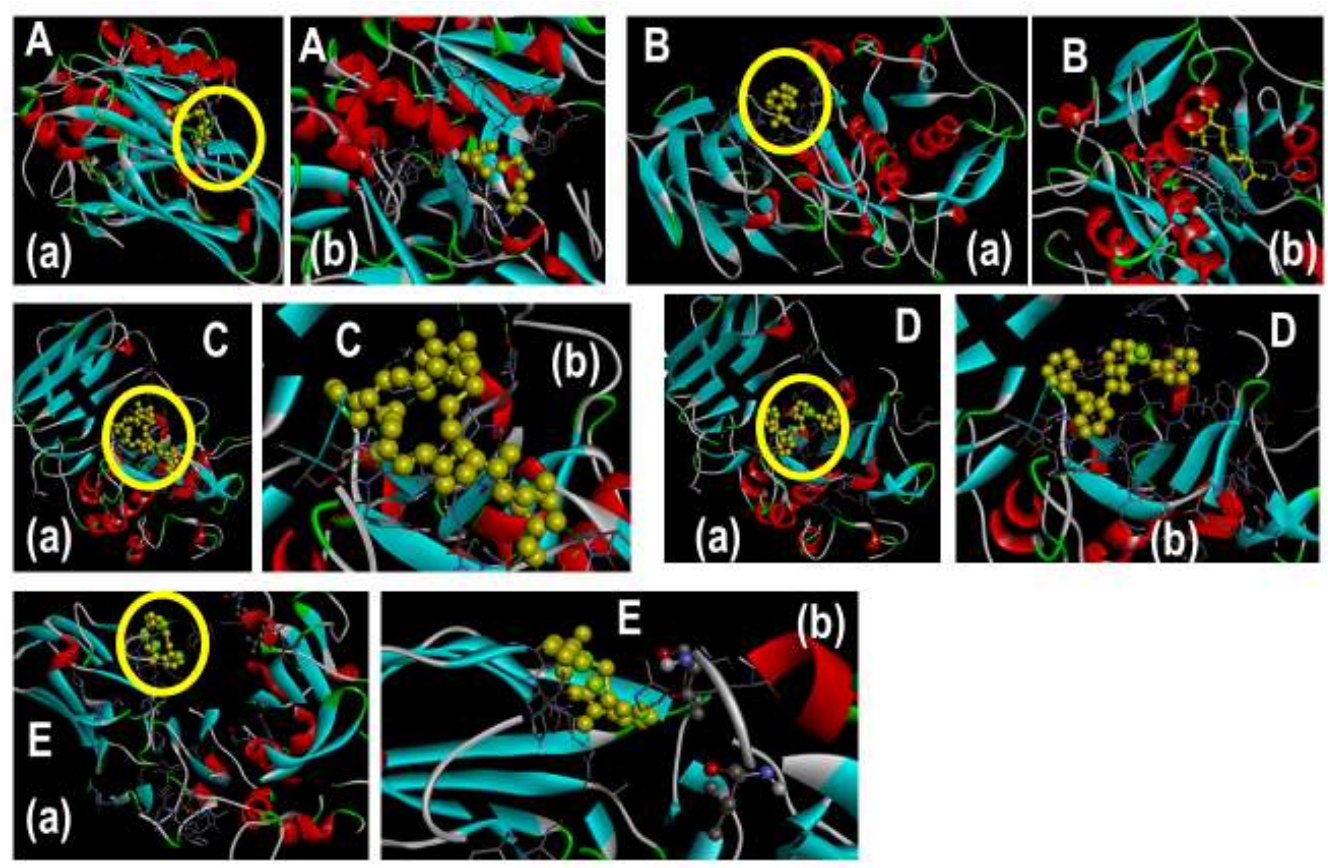
Table 1: Binding energy of the organoselenium compounds, their sulfur analogues and reference molecules (ML188*, Ebselen*, HOCQ* and Remdesvir*) with the target proteins are presented.

\begin{tabular}{|c|c|c|c|c|c|c|c|}
\hline \multirow{3}{*}{$\begin{array}{l}\text { Sr. } \\
\text { Nos }\end{array}$} & \multirow{3}{*}{ Compounds } & \multicolumn{6}{|c|}{ Binding Energy $(\mathrm{kcal} / \mathrm{mol})$} \\
\hline & & \multicolumn{2}{|c|}{$\begin{array}{c}\text { S protein } \\
\text { (PDB: 6VXX) }\end{array}$} & \multicolumn{2}{|c|}{$\begin{array}{c}\mathrm{M}^{\text {pro }} \\
\text { (PDB: 6LU7) }\end{array}$} & \multicolumn{2}{|c|}{$\begin{array}{c}\text { Furin } \\
\text { (PDB: 5MIM) }\end{array}$} \\
\hline & & $\mathrm{Se}$ & $\mathrm{S}$ & $\mathrm{Se}$ & $\mathrm{S}$ & $\mathrm{Se}$ & $\mathrm{S}$ \\
\hline 1 & DSePA & -4.5 & -4.1 & -4.5 & -3.9 & -5.7 & -4 \\
\hline 2 & CysSeSeCys & -5.5 & -5.2 & -4.7 & -4.3 & -5.1 & -5.1 \\
\hline 3 & DSePAmine & -3.6 & -3.5 & -3.3 & -3.1 & -3.8 & -3.5 \\
\hline 4 & MeSeCys & -4.2 & -4.5 & -4 & -4.1 & -4.3 & -4.3 \\
\hline 5 & $\mathrm{SeM}$ & -4 & -4 & -3.4 & -3.9 & -4.5 & -3.9 \\
\hline 6 & Se-His & -5.7 & -5.8 & -4.7 & -4.7 & -6.1 & -6 \\
\hline 7 & GSeSeG & -6.6 & -7.3 & -5.1 & -5.5 & -6.9 & -7 \\
\hline 8 & $\mathrm{PhSeSePh}$ & -5.8 & -5.2 & -5.2 & -5 & -6.5 & -5.7 \\
\hline 9 & DHS & -4 & -4 & -3.8 & -3.8 & -4.2 & -4.2 \\
\hline 10 & $\mathrm{MSeA}$ & -3.8 & -3 & -3.1 & -3.1 & -3.3 & -3.2 \\
\hline 11 & $\mathrm{SeU}$ & -3.1 & -3.6 & -3.2 & -3.3 & -3.5 & -3.5 \\
\hline 12 & EbSe & -6.3 & -6.3 & -5.4 & -5.4 & -6.5 & -6.6 \\
\hline 13 & $\mathrm{EbSeSeEb}$ & -9.4 & 8 & -7 & -6.2 & -8.7 & -7.9 \\
\hline 14 & NictSeSeNict & -8.1 & -7.4 & -6.6 & -5.7 & -7.7 & -7.1 \\
\hline 15 & HOPySeSePyOH & -6.8 & -6 & -5.8 & -5 & -6.7 & -6.3 \\
\hline 16 & CarPySeSePyCar & -7.1 & -6.4 & -5.8 & -5.2 & -6.8 & -6.3 \\
\hline 17 & 2-PySeSePy & -6.1 & -5.6 & -5.1 & -4.8 & -5.9 & -5.7 \\
\hline 18 & 4-PySeSePy & -5.3 & -5.4 & -4.5 & -4.2 & -5.5 & -5.5 \\
\hline 19 & EbSeH & -6.0 & -6.1 & -5.1 & -5.2 & -5.8 & -5.8 \\
\hline 20 & NictSe & -5 & -5 & -4.3 & -4.4 & -5.3 & -5.3 \\
\hline 21 & Nicotinamide $^{\#}$ & -5 & & -4.3 & & -5.4 & \\
\hline 22 & HOCQ* & -6.3 & & -4.9 & & -6.4 & \\
\hline 23 & Remdesivir* & -8.2 & & -3.2 & & -8.3 & \\
\hline 24 & ML188 & -5.8 & & -5.4 & & -7.0 & \\
\hline
\end{tabular}


Table 2: Binding constant for target proteins and $\log \mathrm{P}$ values of the organoselenium compounds, their sulfur analogues and reference molecules (ML188*, Ebselen*, HOCQ* and Remdesvir*) are presented.

\begin{tabular}{|c|c|c|c|c|c|c|c|c|c|}
\hline \multirow{3}{*}{$\begin{array}{l}\text { Sr. } \\
\text { Nos }\end{array}$} & \multirow{3}{*}{ Compounds } & \multicolumn{6}{|c|}{ Binding Constant $\left(\mathrm{M}^{-1}\right)$} & \multicolumn{2}{|c|}{$\log P$} \\
\hline & & \multicolumn{2}{|c|}{$\begin{array}{c}\text { S protein } \\
\text { (PDB: 6VXX) }\end{array}$} & \multicolumn{2}{|c|}{$\begin{array}{c}\mathrm{M}^{\text {pro }} \\
\text { (PDB: 6LU7) }\end{array}$} & \multicolumn{2}{|c|}{$\begin{array}{c}\text { Furin } \\
\text { (PDB: 5MIM) }\end{array}$} & & \\
\hline & & $\mathrm{Se}$ & $\mathrm{S}$ & $\mathrm{Se}$ & $\mathrm{S}$ & $\mathrm{Se}$ & $\mathrm{S}$ & $\mathrm{Se}$ & $\mathrm{S}$ \\
\hline 1 & DSePA & 2005.3 & 1020.1 & 2005.3 & 727.6 & 15232.3 & 861.5 & 0.6 & 0.37 \\
\hline 2 & CysSeSeCys & 10864.3 & 6544.2 & 2811.6 & 1430.3 & 5526.8 & 5526.8 & -4.75 & -4.86 \\
\hline 3 & DSePAmine & 438.3 & 370.1 & 264.0 & 188.3 & 614.5 & 370.1 & -0.82 & -1.05 \\
\hline 4 & MeSeCys & 1207.9 & 2005.3 & 861.5 & 1020.1 & 1430.3 & 1430.3 & -2.39 & -2.51 \\
\hline 5 & SeM & 861.5 & 861.5 & 312.6 & 727.6 & 2005.3 & 727.6 & -2.12 & -2.24 \\
\hline 6 & Se-His & 15232.3 & 18036.3 & 2811.6 & 2811.6 & 29942.9 & 25287.9 & -5.14 & -5.41 \\
\hline 7 & GSeSeG & 69695.3 & 227445.2 & 5526.8 & 10864.3 & 115704.3 & 137003.4 & -6.08 & -6.11 \\
\hline 8 & $\mathrm{PhSeSePh}$ & 18036.3 & 6544.2 & 6544.2 & 4667.6 & 58860.2 & 15232.3 & 4.97 & 4.4 \\
\hline 9 & DHS & 861.5 & 861.5 & 614.5 & 614.5 & 1207.9 & \begin{tabular}{|l|}
1207.9 \\
\end{tabular} & -0.47 & -0.59 \\
\hline 10 & MSeA & 614.4 & 159.0 & 188.3 & 188.3 & 264.0 & 223.0 & 0.68 & -2.04 \\
\hline 11 & $\mathrm{SeU}$ & 188.3 & 438.2 & 223.0 & 264.0 & 370.1 & 370.1 & -0.34 & -0.46 \\
\hline 12 & EbSe & 41981.5 & 41981.5 & 9175.3 & 9175.3 & 58860.2 & 69695.3 & 2.92 & 3.16 \\
\hline 13 & EbSeSeEb & 7904897 & 742249.6 & 137003.4 & 35454.9 & 2422273.1 & 626856.5 & 6.65 & 6.09 \\
\hline 14 & NictSeSeNict & 878884.6 & 269313.9 & 69695.3 & 15232.3 & 447099.7 & 162223.3 & 0.71 & 0.47 \\
\hline 15 & HOPySeSePyOH & 97716.4 & 25287.9 & 18036.4 & 4667.6 & 82525.0 & 41981.5 & 2.63 & 2.4 \\
\hline 16 & CarPySeSePyCar & 162223.3 & 49709.6 & 18036.4 & 6544.2 & 97716.4 & 41981.5 & 2.21 & 1.98 \\
\hline 17 & 2-PySeSePy & 29942.9 & 12864.3 & 5526.8 & 3329.1 & 21356.5 & 15232.3 & 3.17 & 2.93 \\
\hline 18 & 4-PySeSePy & 7748.9 & 9175.3 & 2005.3 & 1207.9 & 10864.3 & 10864.3 & 2.39 & 1.83 \\
\hline 19 & $\mathrm{EbSeH}$ & 25287.9 & 29942.9 & 5526.8 & 6544.2 & 18036.4 & 18036.4 & 2.88 & 3.01 \\
\hline 20 & NictSe & 4667.6 & 4667.6 & 1430.3 & 1693.6 & 7748.9 & 7748.9 & 0.46 & -0.53 \\
\hline 21 & Nicotinamide & 4667.6 & & 1430.3 & & 9175.3 & & -0.48 & \\
\hline 22 & HOCQ* & 41981.5 & & 3942.0 & & 49709.6 & & 4 & \\
\hline 23 & Remdesivir* & 1040672 & & 223.0 & & 1232240.9 & & 2.82 & \\
\hline 24 & ML188 & 4667.6 & 4667.6 & 9175.3 & & 137003.4 & & 4.67 & \\
\hline
\end{tabular}


Table 3: The amino acid residues involved in the binding of orgnoselenium compounds with SARS-CoV-2S protein (PDB Code: 6VXX). Vander Waals binding, pi-alkyl interaction, pi-cation attraction interaction and repulsive interaction respectively.

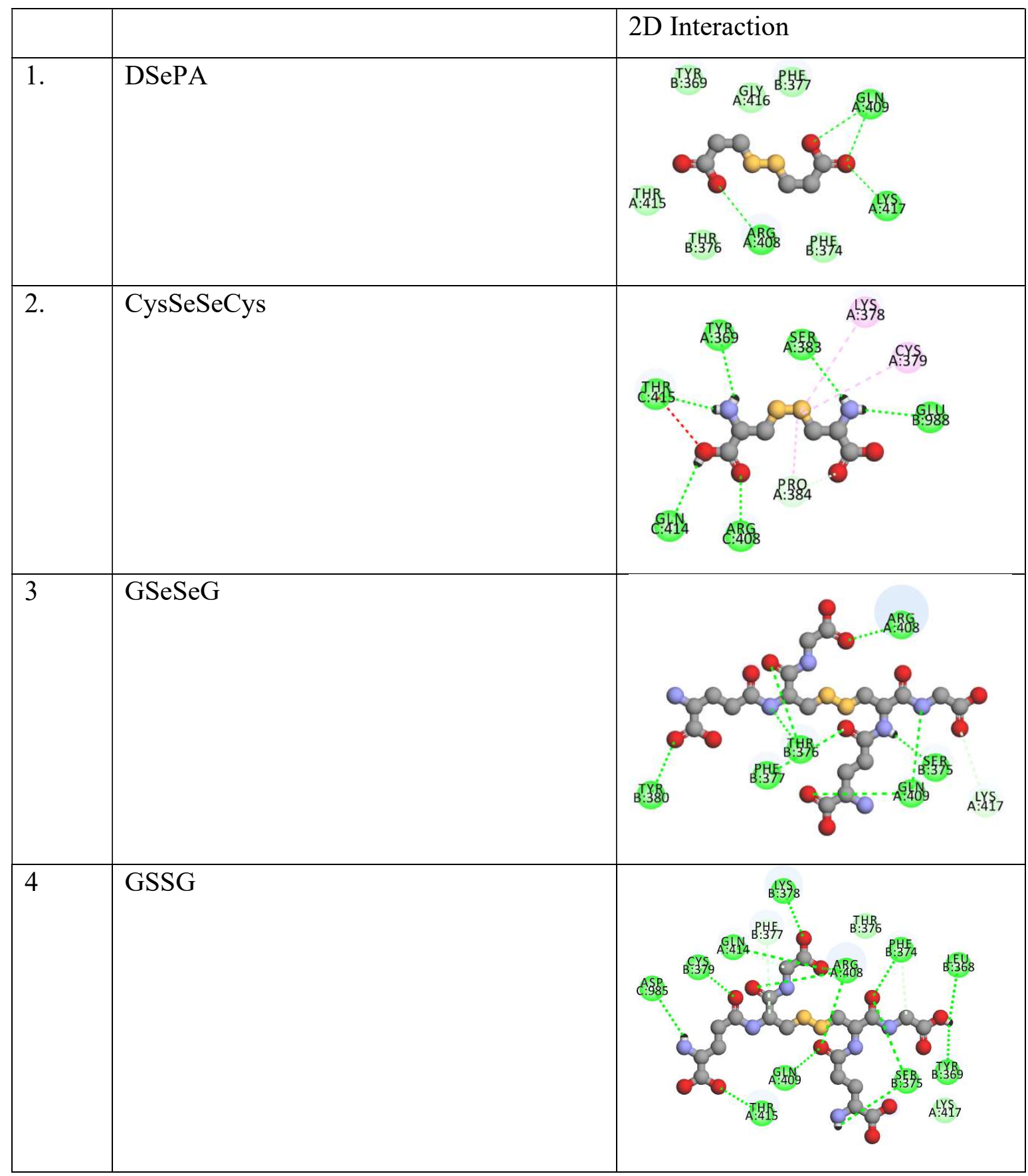




\begin{tabular}{|c|c|c|}
\hline 5 & NictSeSeNict & A:LE4 \\
\hline 6 & Ebselen & 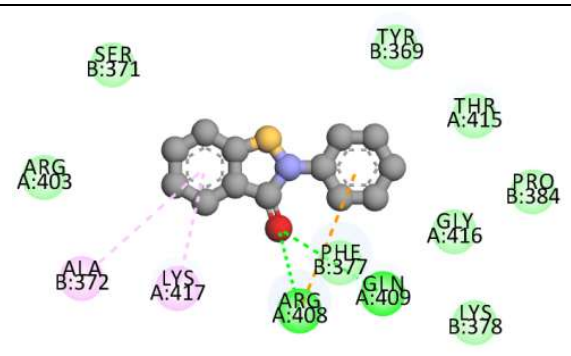 \\
\hline 7 & Ebselendiselenide & A:RG \\
\hline 8 & HOCQ & 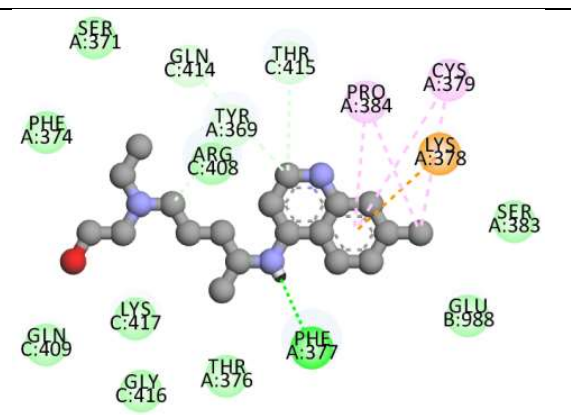 \\
\hline 9 & Remdesvir & 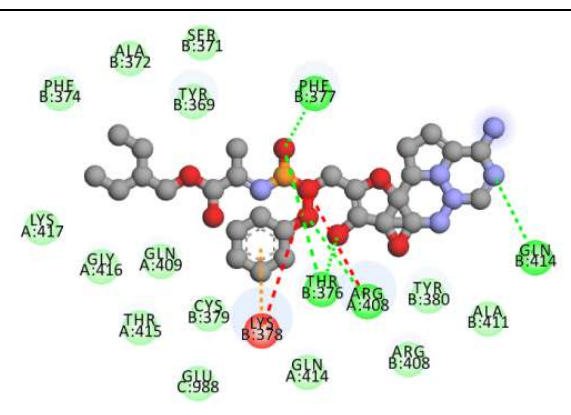 \\
\hline
\end{tabular}




\begin{tabular}{|c|c|c|}
\hline 10 & ML-188 & A:396 \\
\hline
\end{tabular}


Table 4: The amino acid residues involved in binding of the orgnoselenium compounds and the SARS-CoV-2 $\mathrm{M}^{\text {pro }}$ protein (PDB Code: 6LU7). $O 00$ represents hydrogen bonding, Vander Waals binding, pi-alkyl interaction, pi-cation attraction interaction and repulsive interaction respectively.

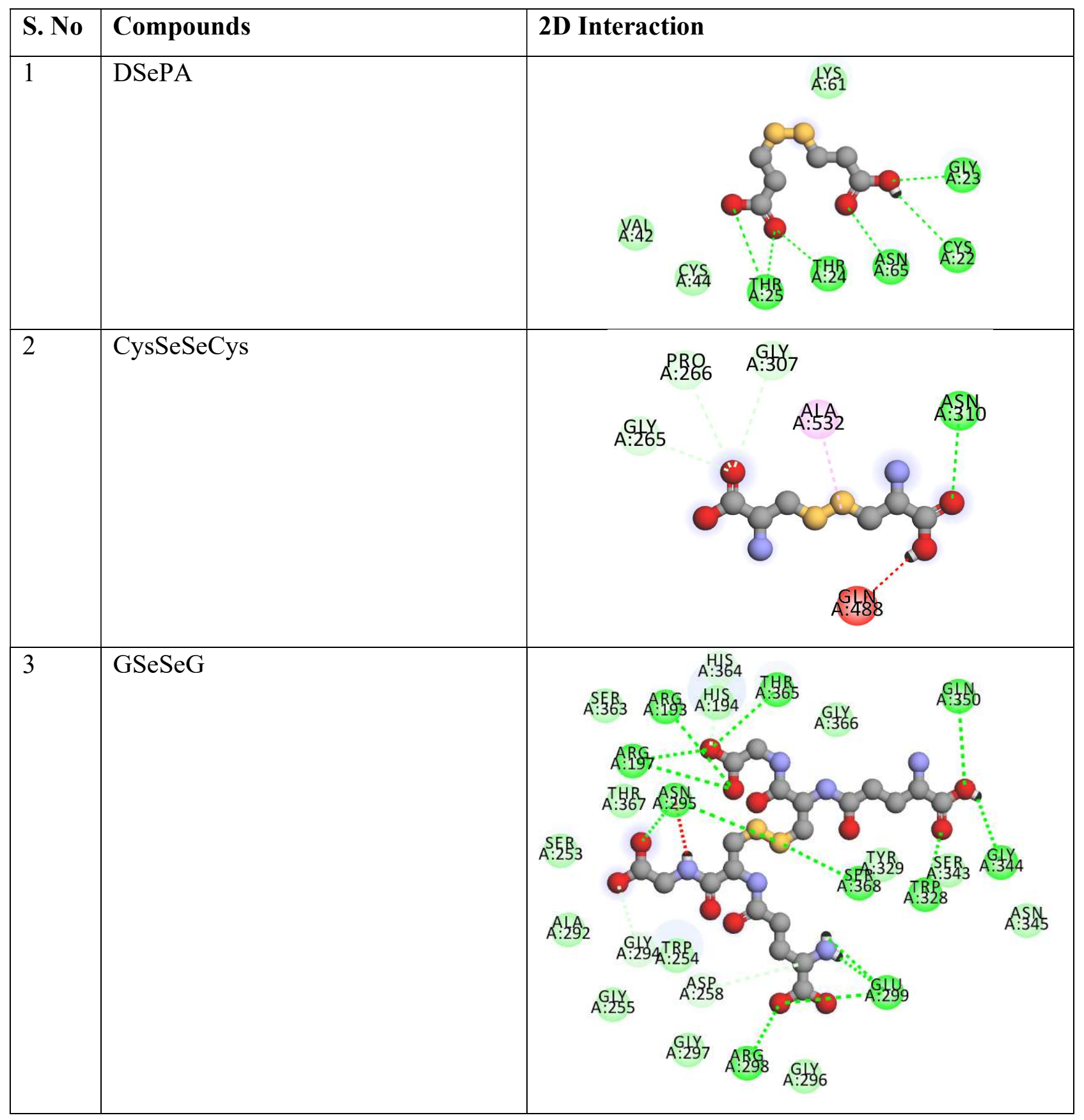




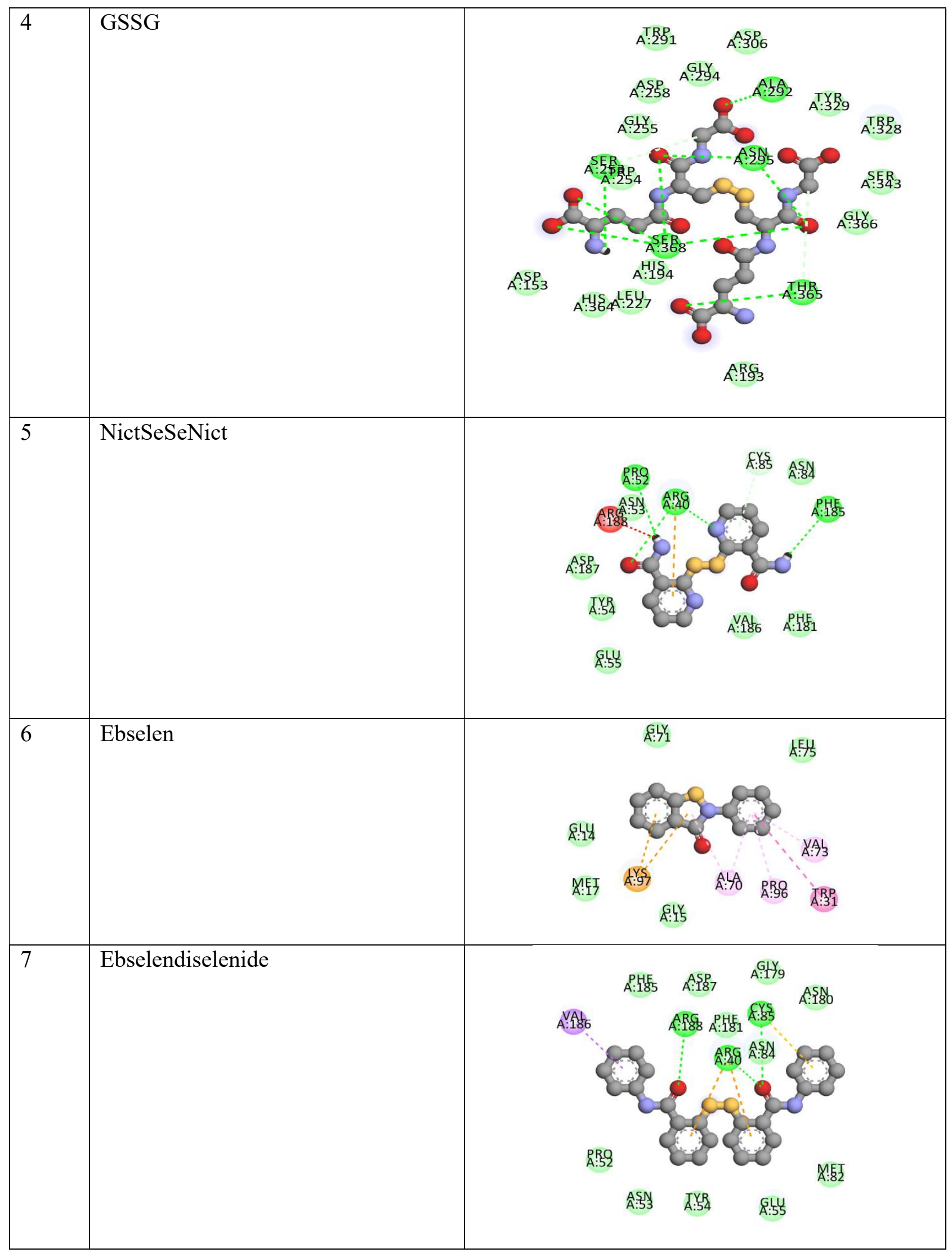




\begin{tabular}{|c|c|c|}
\hline 8 & HOCQ & ASY \\
\hline 9 & Remdesvir & 6.480 \\
\hline 10 & ML 188 & A:S:192 \\
\hline
\end{tabular}


Table 5: The amino acid residues involved in binding of the orgnoselenium compounds and the Furin protein (PDB Code: 5MIM). $O O O$ represents hydrogen bonding, Vander Waals binding, pi-alkyl interaction, pi-cation attraction interaction and repulsive interaction respectively.

\begin{tabular}{|c|c|c|}
\hline S. No & Compounds & 2D Interaction \\
\hline 1 & DSePA & A: \\
\hline 2 & CysSeSeCys & A:266 A:307 \\
\hline 3 & GSeSeG & 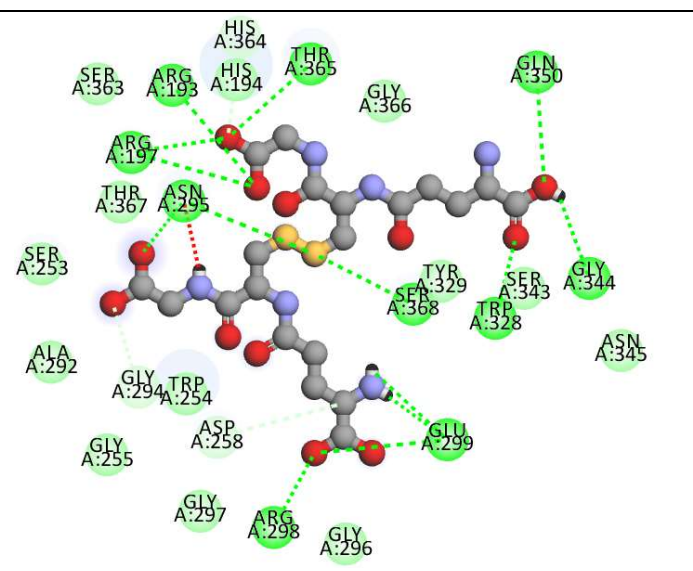 \\
\hline
\end{tabular}




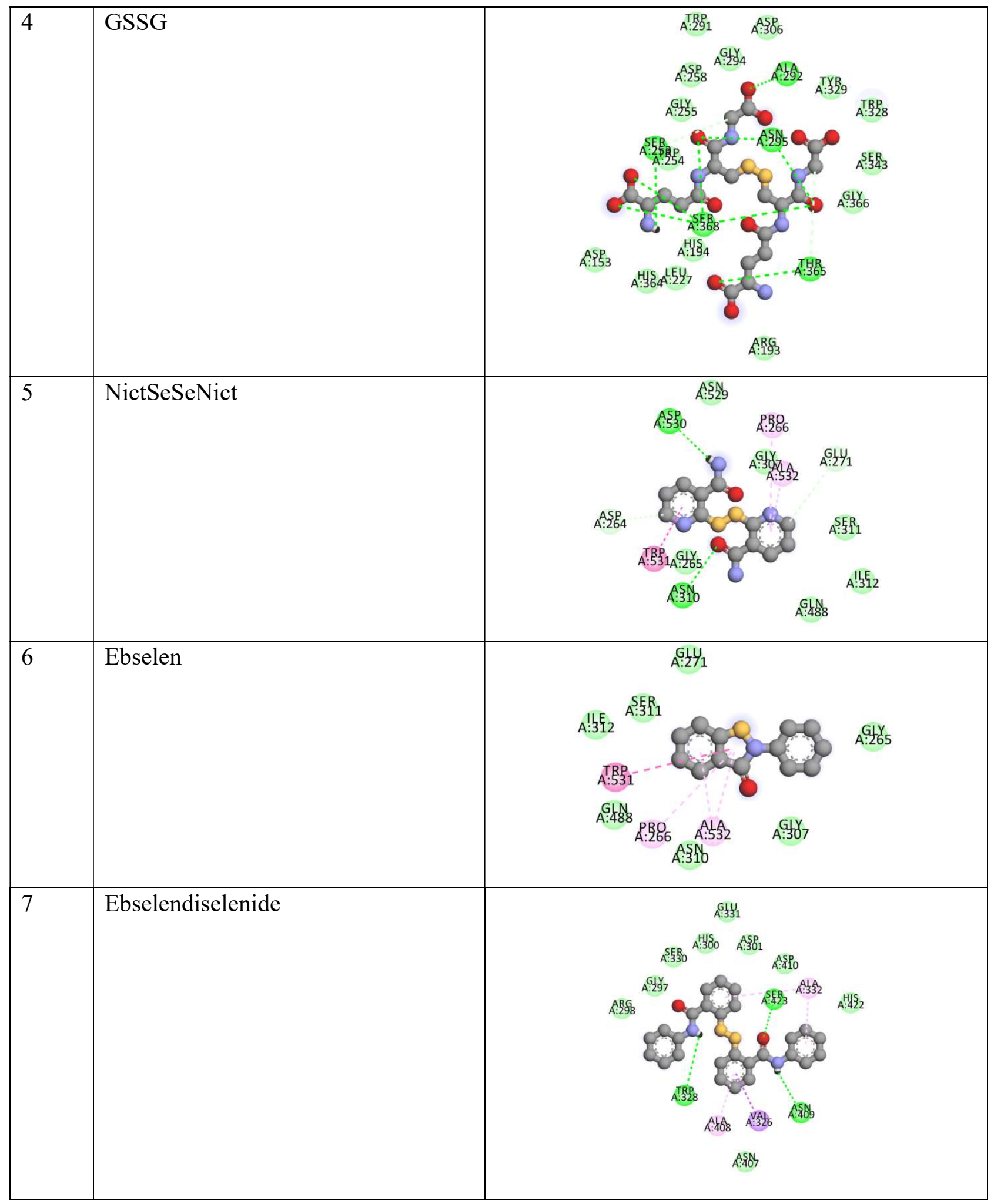




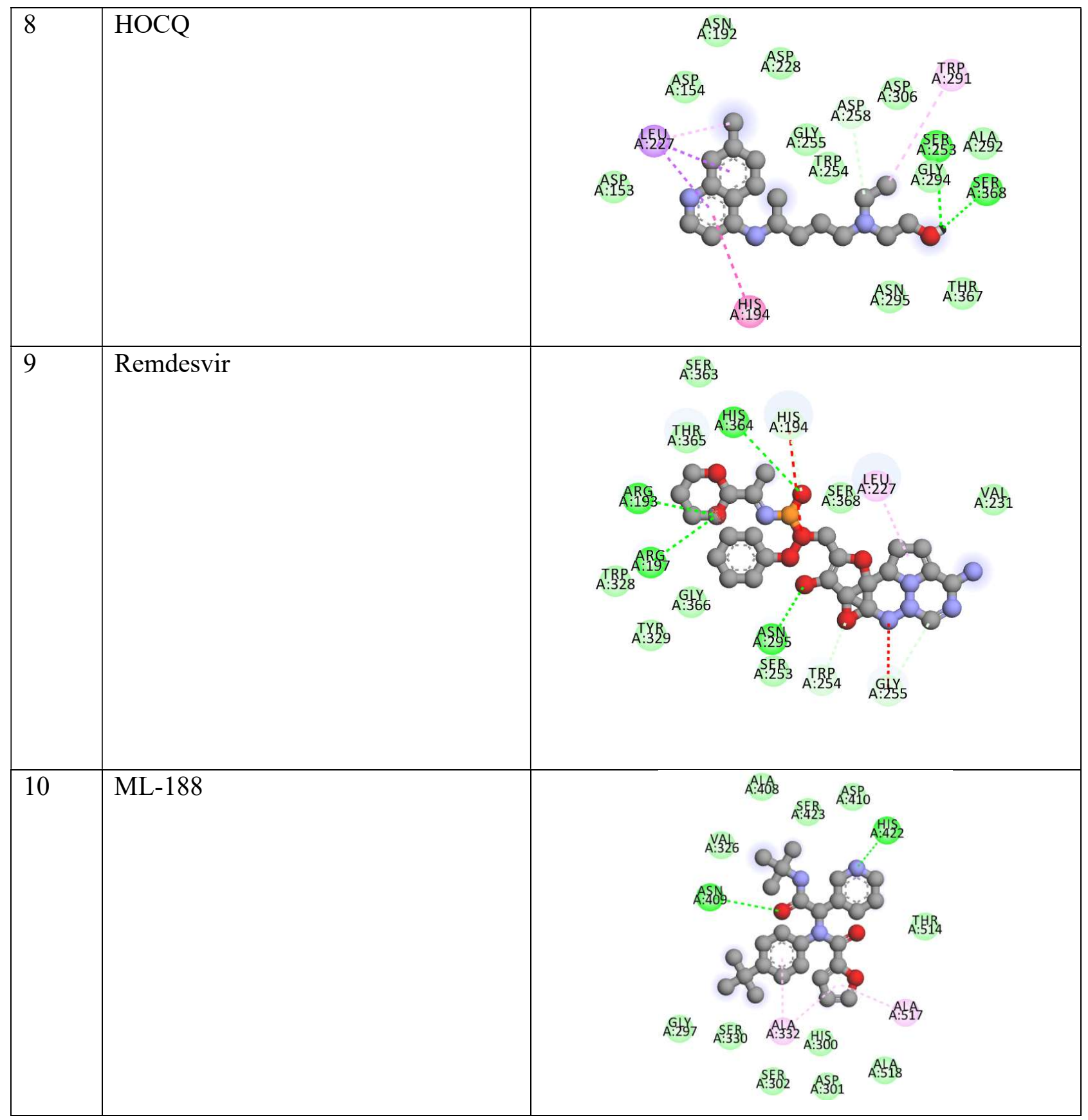

